Article

\title{
Determining the Sustainability Factors and Performance of a Tourism Destination from the Stakeholders' Perspective
}

\author{
Manuel Rodríguez Díaz * and Tomás F. Espino Rodríguez \\ Department of Business and Management, Universidad de Las Palmas de Gran Canaria, \\ Las Palmas de Gran Canaria 35017, Spain; tomasfrancisco.espino@ulpgc.es \\ * Correspondence: manuel.rodriguezdiaz@ulpgc.es; Tel.: +34-928-452-805 \\ Academic Editor: Rachel Dodds \\ Received: 12 June 2016; Accepted: 14 September 2016; Published: 19 September 2016
}

\begin{abstract}
The competitiveness of a tourism destination depends on the sustainability of its economic and environmental resources. The aim of this paper is to determine the key factors in achieving the sustainability of a tourism destination in relation to the performance obtained. A methodology based on the opinions of stakeholders is developed to determine the sustainability factors and performance in the tourism destination of Gran Canaria. The variables used in the study are related to the environmental resources, the principal agents in the tourism supply chain, the governance of the destination, and the complementary characteristics that improve the competitiveness of the tourism destination, as well as the dimensions that determine security. Performance is measured by stakeholders from two perspectives, the destination and the customers, in order to establish the main variables that will influence the destination's sustainability. The key sustainability factors were identified, and a regression analysis determined that there was a positive influence on long-term performance. The results showed that the key factors that have a direct and significant relationship with performance are the key resources and supply chain, security, alternative leisure, and governance.
\end{abstract}

Keywords: tourism destination; sustainability; stakeholders; performance; tourism resources; destination management

\section{Introduction}

A tourist destination is considered a complex and open system that, as a whole, establishes an offer capable of attracting tourists in the long term. In this context, a tourism destination is composed of complex networks with a large number of resources and co-producing actors delivering a variety of products and services [1-8]. In an increasingly saturated marketplace, the development and promotion of a tourist destination must be guided by analytic frameworks that focus on the concept of competitiveness [9]. Thus, the combined success of individual actors and the entire destination depends on the efficient coordination and integration of individual companies' resources, capabilities, products and services [10,11], as well as a leadership and governance of the destination based on close cooperation among all of the agents involved $[9,12,13]$.

In the complex system that makes up a destination, sustainability and sustainable development are key concepts in maintaining long-term competitiveness. This idea emerges as an alternative to the traditional neo-classical model of economic development based on economic benefits without taking into account the negative social, cultural, and environmental impacts [14]. Traditionally, tourism destinations grew spontaneously without planning. The consequences were damage to nature and socio-cultural environments, transforming economic development into a loss of both competitiveness 
and the opportunity to achieve a sustainable performance over time $[8,9,14-19]$. These circumstances led to the need to change the orientation of tourism destinations, providing integrated objectives designed to obtain the conservation and preservation of natural and cultural resources, quality of life, and long-term economic viability $[8,9,11,14,17,18,20-27]$.

The aim of this study is to determine the key sustainability factors and their relationship with the performance of tourism destinations, in order to propose a framework that can facilitate the decision-making process and achieve the integrated objectives of the resources, capabilities, and agents involved. The methodology proposed contributes to developing the practical and effective management of tourism destinations and to building a sustainable, long-term competitive advantage. In this context, an economically and environmentally sustainable tourism destination must produce sustainable performance, forming the basis for the development of a sustainable competitive advantage. The paper begins with a literature review about tourism destinations, stakeholder studies, sustainability, and performance as an integrated objective shared by all the agents. The next section describes the research methodology and the variables used in the statistical analyses. Then, the paper presents the results that determine the sustainability factors and the performance of the tourism destination and customers. Finally, the conclusions, limitations, and lines for future research are described.

\section{Literature Review}

The tourism destination is an important topic in the literature because it is a global concept that has a decisive influence on the choice of tourist trips. Pavlovich [28] establishes that "the tourism destination generally comprises different types of complementary and competing organizations, multiple sectors, infrastructures, and an array of public/private linkages that create a diverse and highly fragmented supply structure". In this context, Pike and Page [13] consider that "a destination represents an amalgam of a diverse and eclectic range of businesses and people who might have a vested interest in the prosperity of their destination community". The complex and close interrelationships among the resources and agents of the destination mean that the success of individual and cooperative ventures will depend on the destination's competitiveness [29-31]. Likewise, the stakeholders' leadership is also critical to achieving the competitive objectives of the destination [32]. The governance of the destination has also been studied in the specialized literature because the destination needs all of the agents to share common objectives in order to obtain a competitive advantage over other destinations [10,33]. A competitive advantage can be achieved if the overall appeal of a tourism destination is superior to alternative destinations with similar target market segments $[34,35]$. Therefore, a destination's competitiveness must be focused on the ability to create added value by managing assets and processes. This is achieved by integrating the relationships of stakeholders within a tourism planning model [36] that takes into account a destination's natural, social, and economic resources, and its preservation for future generations [37-39]. In this line, the destination's marketing organization is now acknowledged as a mainstay of the future development and sustainability of the tourism destination and an important way to compete and attract visitors [13,40,41]. Moreover, due to the complexity and great difficulty of obtaining information about the different perspectives involved in the tourism destination, most studies have been based on the opinions of experts and stakeholders [11,12,35,39,42-44].

The idea of sustainable development was first proposed by the International Union for the Conservation of Nature and Natural Resources [45]. Some years later, the Brundtland Commission Report defined sustainable development as "development that meets the needs of the present without compromising the ability of future generations to meet their own needs" [46]. In the field of tourism, different authors have proposed a variety of definitions of sustainability and sustainable development $[47,48]$, but the most well-known is the definition proposed by the World Tourism Organization [49] establishing that "sustainable tourism development meets the needs of present tourists and host regions while protecting and enhancing opportunities for the future. It is envisaged as leading to the management of all resources in such a way that economic, social and aesthetic 
needs can be fulfilled while maintaining cultural integrity, essential ecological processes, biological diversity and life support systems". Moreover, [50] analyzes three sustainability traditions in tourism studies: resources, activities, and community tradition, and Ko [51] identifies eight dimensions of sustainable tourism development divided into two sub-systems. The human system includes the political, economic, and socio-cultural aspects, and the production structure (the quality of services and products for tourism), whereas the ecosystem deals with the quality of water, land and air, the biodiversity of flora and fauna, and environmental policy and management. Along these lines, [52] considers that the environmental management of a tourist destination should be a source of competitiveness. Likewise, Byrd et al. [43] identified five factors of a stakeholder's understanding of sustainable tourism development: (1) natural resources; (2) planning; (3) economic concerns; (4) educational needs; and (5) awareness of tourism. In this context, the national tourism organization can play a decisive role in achieving sustainable tourism through strategic planning designed to improve performance [53].

Although the sustainability of tourism destinations is a widely accepted and studied concept, some authors, like Liu [17], highlight some weaknesses, such as: (1) attention is not paid to the tourism demand at the destination level; (2) discussion of resource sustainability usually fails to appreciate that resources evolve with the changing needs, preferences, and technological capabilities of society; and (3) many writers and practitioners enthusiastically promote new types of tourism that are more linked to sustainability (e.g., ecotourism, alternative tourism, responsible tourism, soft tourism, low-impact tourism, community tourism), but experience shows that none of these forms can properly combine sustainable development with the growing tourism industry worldwide. In this context, sustainable tourism requires both the sustainable growth of tourism's contribution to the economy and society and the sustainable use of resources and the environment based on the analysis of the tourism demand $[17,47,54]$. In the literature, no studies have focused on determining or analyzing the key sustainability factors in relation to performance as a way to support the decision-making process of managers in order to maintain or increase the competitiveness of the tourism destination. The study of this critical aspect makes it possible to propose frameworks and methodologies that facilitate management models for sustainable destinations with regard to competitive performance.

The development and creation of new tourism destinations all over the world has increased the competition to capture the proposed level of demand. To guarantee viability and profitability, tourism destination managers have to ensure the destinations' success with performance and competitiveness based on productivity and marketing models [55]. Few articles have studied destination performance, even though it is a key tool for managing the destination. The majority have analyzed different aspects of performance, such as image [56-58], advertising [59], price [60], loyalty [61,62], production processes and management efficiency [55,63-65], and the data envelopment analysis approach [66,67]. Another study that focuses on performance in the tourism industry was carried out by Assaf and Josiassen [68]. They created a tourism performance index with the aim of elaborating a ranking of countries. These authors consider that there are eight drivers of tourism performance: (1) tourism and related infrastructure; (2) economic conditions; (3) security, safety, and health; (4) tourism price competitiveness; (5) government policies; (6) environmental sustainability; (7) labor skills and training; and (8) natural and cultural resources. Therefore, there are no specific studies on performance in relation to the sustainability of the tourism destination. In this context, performance must be considered in the long term because this is the only way to achieve the sustainable development of the destination, the economy, and society. Moreover, performance can be analyzed from different perspectives. In this study, the performance of the tourism destination is measured from two perspectives. In the first, we include the variables that measure specific aspects of the destination, such as the occupancy, quality, economy, employment, etc., whereas the other view is based on the measurement of customers' performance through loyalty, emotional experience, and image. In conclusion, it is necessary to develop theoretical and practical models that determine the key sustainability factors of a tourism destination's sustainability, in order to maintain or increase its competitiveness. In this context, these factors must 
be defined and managed with the purpose of achieving a high and sustainable performance level. The variables of the key factors represent the resources and capabilities of the tourism destination, which must be sustainable both economically and environmentally in order to produce a positive and continuous impact on the society. Therefore, the key sustainability factors are the drivers in managing sustainable tourism destinations with the aim of obtaining sustainable performance. At the same time, the performance achieved is necessary to develop continuous improvement and, consequently, accomplish a sustainable long-term competitive advantage. Thus, the objective of this study is to propose a methodology and test it in the tourism destination of Gran Canaria, with the aim of identifying the sustainability factors and their relationships with the performance of the destination and customers, based on the evaluations of stakeholders.

\section{Research Methodology}

To carry out the study, a stakeholder survey was conducted in the tourism destination of Gran Canaria (Canary Island, Spain), one of the most important destinations in Europe. In 2013, the Canary Islands received more than 12 million tourists; specifically, Gran Canaria Island had $3,384,264$ tourists in the same time period. These numbers set a record, as it is a consolidated destination that has a high level of security and is integrated in the European Union. This destination is classified as sun and beach and has a high demand all year, but the highest demand is in the winter season. The main tourism markets of Gran Canaria are Germany (22.18\%), the United Kingdom $(15.41 \%)$, Norway (11.04\%), and Sweden (9.84\%). The number of hotel beds in Gran Canaria is about 62,647, while the number of non-hotel beds is around 69,689 [69]. These data show a transformation in the tourism lodging offer in Gran Canaria, reducing non-hotel beds and increasing hotel beds in order to adapt to the new needs of tourists.

The methodology applied is based on expert or stakeholder opinions, a widely developed research method in the academic literature on tourism [11,12,35,39,42-44]. A survey with 55 respondents was administered to stakeholders related to the most strategic tourism areas, structured in the following way: 12 hotel managers, 11 managers of non-hotel accommodations, nine managers of complementary offers, six managers of service companies, seven politicians, six managers of tour operators and travel agencies, and four researchers who are experts in tourism-related issues. The selection of the experts was based on their relevance in the tourism sector on the island of Gran Canaria. Moreover, the most significant experts in the groups of stakeholders involved were included in the sample in order to obtain reliable information about the scales for the variables proposed. The method used to select the stakeholders surveyed in Gran Canaria had three steps. First, the seven groups of stakeholders best suited to achieving the objectives of this study were defined. In the second step, a list of possible people in each group was prepared, with the restriction that they had to be experts and hold an important management position in major companies or organizations. In the case of the research experts, they were selected based on their knowledge and academic experience in tourism. Moreover, the politicians make up a group that is more difficult to define because they do not always remain in the tourism area for a long time, and they are not normally technical experts in managing the destination. Therefore, the politicians selected had to have practical experience in planning and managing the tourism destination at the level of the Canary Government, the Cabildo Insular of Gran Canaria, or the Councils of the tourism municipalities. Third, the possible responders were contacted by telephone in order to arrange a personal interview, finally achieving 55 complete surveys because approximately $20 \%$ of the possible responders did not want to fill out the survey. Although the sample was limited, all of the local groups of stakeholders were considered, from politicians related to the planning of the tourism destination, to managers of hotels closely linked to the sustainability of the environment and the economy of the destination. Furthermore, a quantitative methodology was used because it was necessary to obtain exploratory knowledge about the sustainability indicators and their relationships with the destination's performance. In order to apply the results to the practical management of the destination, these relationships need to be measured with quantitative methods. 
The objective of the study is to analyze the sustainability factors and their relationships with the long-term performance of a tourism destination. Thus, the questions were posed to measure how each variable is managed and contributes to the sustainability of the tourism destination from a long-term perspective. In addition, the performance variables were measured by focusing on two aspects, the sustainability of the performance of the tourism destination $[55,59,63-65]$ and the customers $[56-58,61,62]$ in the long term. A seven-point Likert scale was used, where 1 indicates the management of the variables without any sustainability criteria, and 7 means high sustainability management. The statistical procedure begins by carrying out a factorial analysis in order to reduce the dimensionality and determine the sustainability factors. In the next step, the factor loadings obtained are introduced in the multiple regression analysis as independent variables to determine their relationships with the dependent variable of sustainable performance. This method makes it possible to test to what extent the key factors are influencing the performance of the destination. Therefore, the factors that obtain significant relationships with sustainable performance are considered keys to driving the sustainability of the destination.

The variables used in the study were selected based on the key resources, capabilities, and aspects that make up the tourism destination and its competitiveness $[9,11,51,68]$. First, the natural resources are the main attraction of the tourism destination, and the variables measured were the sustainability of the "beaches", "weather", "sea environment", and "rural environment" [52,70]. Second, the variables related to the tourism supply chain were measured, such as airline companies, tour operators, travel agencies, and lodging companies [11,71]. Third, the complementary offer of the destination was measured, evaluating sports [72-74], leisure [75], shopping centers [76], and theme parks $[77,78]$. Fourth, the cultural offer has to do with the museums, history, and culture of the population of the tourism destination [79-81]. Fifth, as the security of the destination is one of the most important aspects in tourists' decision-making process, three variables were included in the study. The first is the "sustainability of health", which deals with the physical health risk the tourist accepts when deciding on a destination [82-84]. The second variable is security in terms of delinquency [85-89], and the third is the risk of war, politic instability, or legal security, measured by the variable "sustainability of belonging to Europe". Finally, there are variables related to the governance of the destination by the different public administrations and its strategic planning $[12,13,36,37,90]$. In this context, the sustainability of a resource or capability is measured in the sense that it can be economically profitable over time and, at the same time, have the least impact possible on the environment, in order to preserve resources and allow society to continuously benefit from them. In this context, the sustainability of the airlines, for example, is based on their present and future profitability in accordance with environmental preservation. If the airlines lose profitability, the destination reduces its income, jeopardizing its sustainability and producing an adverse effect on society. On the other hand, if airlines increase their profitability, it is possible that the demand will increase, exceeding the limits of the carrying capacity of the destination, resulting in its degradation and loss of competitiveness. Another example would be membership in Europe, which is perceived by customers as a variable of security. The sustainability of this crucial capacity is based on future permanence in the European Union without losing an economic balance.

In the academic literature on management, the performance of different variables and methodologies has been measured. In tourism destinations, some studies are designed to measure the performance [58,91], but without taking into account the sustainability in relation to the performance obtained in the tourism destination. The most extensive studies about sustainability are focused on tourism resources and pay less attention to the tourism demand, especially at the destination level. Furthermore, "the discussion about resource sustainability is often limited to the preservation and conservation of resources and fails to appreciate that resources are a complex and dynamic concept, evolving with changes in the needs, preferences and technological capabilities of society" [17]. In this context, Hassan [9] considers that "sustaining the longevity of a given destination becomes a function of responding to market demand and competitive challenges. It is critical for future 
destination development plans to be compatible with market needs and environmental integrity in order for the industry to maintain its economic viability". Moreover, Bornhorst et al. [44] identified the variables to measure the destination's success and grouped them into five categories: economic success, products and services, offerings, effective marketing, quality of visitor experiences, and internal stakeholder groups.

Therefore, the variables used to measure the performance of a tourism destination can be divided according to two perspectives. The performance of the resources, capabilities, and stakeholders of the tourism destination and the performance obtained by the visitors. In this study, the questions about the performance were designed to evaluate the future performance of the destination and customers. This is an alternative way to measure the sustainability of performance because it focuses on the future environmental, social, and economic viability of a destination. The first perspective of performance is the offer, which must combine various elements and areas, such as the environment, the economy, and the society integrated in cooperative governance. In this context, the construction of sustainable development occurs only when the quality of the environment and community life can be sustained in the long run $[9,53]$. The other perspective of performance is the demand, which looks for a unique and different experience for visitors at the destination [17]. The variables used to determine the tourism destination's performance were divided into three groups. The first focuses on measuring the general performance of the tourism destination, and it includes four variables (see Table 1) that determine the competitiveness [92], quality [93], tourist satisfaction [94,95], and overall sustainability of the destination [14,52]. These variables measure the resources and capabilities of the tourism destination as an integrated whole, including environmental conservation and economic and social impacts.

Table 1. Variables to measure the future performance.

\begin{tabular}{l} 
Future Performance of the Tourism Destination \\
\hline Sustainability of the competitiveness of the destination \\
Sustainability of the quality of the destination \\
Sustainability of the satisfaction of the tourists \\
Sustainability of the tourism destination \\
Sustainability of the tourists' spending \\
Sustainability of the profits of the tourism sector \\
Sustainability of the annual occupancy level \\
Sustainability of the tourists' extra spending \\
Sustainability of the satisfaction of the employers in the tourism sector \\
Sustainability of the impact on the economy of the island \\
Sustainability of the impact in the future development of the island \\
Sustainability of the stability and increase in employment \\
Sustainability of the cooperation among the economics agents \\
\hline Future Performance of the Customers \\
\hline Sustainability of the loyalty of customers \\
Sustainability of the emotional experience \\
Sustainability of the image
\end{tabular}

As economic viability is critical to guaranteeing the sustainability of a destination in the long term [9], the second group of variables has the objective of determining the sustainability of the performance in the tourism sector. These are economic variables focused on economic indicators, such as tourists' level of spending and extra spending, annual average occupancy, company profits, and employer satisfaction in this economic sector [14,51]. The third group measures the economic impact of the tourism industry on the sustainability of the global economy of the island [44]. The variables used in the study are the sustainability of "the impact on the economy of the island", "the impact on the future development of the island", and "the stability and increase in employment". According to Hassan [9], the large number of industries involved in creating and sustaining destinations requires the development of a competitiveness model that examines the amount of cooperation needed for 
future competitiveness $[11,13,41]$. For this purpose, the sustainability variable "cooperation among the economic agents" was included [96]. In addition, Table 1 also displays the variables used to determine the sustainability of the customers' performance evaluated by the stakeholders surveyed. The aim is to measure the attitudes of customers with regard to the image perceived [56-58,97], loyalty [61,62], and emotional experience [98], which is a useful way to establish the attitude of tourists about their experiences and satisfaction with the destination.

\section{Analysis of Results}

This section has been divided into three parts: sustainability factors, performance of sustainability, and discussion of the results. In the first, we show the results obtained in determining the main sustainability factors of the tourism destination analyzed. Moreover, the performance obtained by the tourism destination is essential to determining the long-term competitiveness. In this context, the performance must be closely related to the sustainability factors in order to define the key resources and capabilities of the destination. Based on this analysis, those who govern the destination will be able to implement a competitive strategy oriented toward balancing the objectives of maximum performance and the sustainability of the tourism destination. Finally, we discuss the results in order to highlight the main contributions of the study.

\subsection{Sustainability Factors}

Table 2 shows the factor analysis where six latent variables were extracted. The explained variance was $76.71 \%$, and the Kaiser-Meyer-Olkin (KMO) was 0.757 , demonstrating that the results obtained are useful. Likewise, the Cronbach's alphas were high for factors 1 (0.938), 2 (0.822), 3 (0.786), and 4 (0.904). The score obtained for factor 5 was 0.685 , near the recommended level of 0.7 . Factor 6 only has one variable, and it is not necessary to calculate the reliability indicator. These results show that the scale used to measure sustainability is reliable and has factorial consistency.

Six sustainability factors were obtained that describe the main dimensions influencing the sustainability of the tourism destination analyzed. The first factor was called "key resources and supply chain" because it included, on the one hand, all of the variables related to the basic resources that constitute the attractiveness of the tourism destination and, on the other hand, the basic elements of the tourism supply chain to deliver all of the services to customers. First, the natural resources make up the destination's main attraction to capture customers, compared to other competitive destinations. In Gran Canaria, there are several tourism resources, but the most important ones are the weather (sun), with a factorial loading of 0.723 , and the beach (0.845), marine (0.851), and rural $(0.840)$ environments. In addition, the elements of the tourism supply chain that were assigned to this factor are the sustainability of foreign tour operators (0.847), airlines (0.821) and hotels in both categories analyzed (four and five stars versus three stars or less), with scores of 0.696 and 0.561 , respectively. Finally, golf is a complementary offer that is included as one of the destination's main attractions, with a loading of 0.753 , as it is an activity with a growing demand, and the consumers have high income levels. These results show that the experts judge the sustainability of the tourism destination on the basis of enhancing the natural resources, the lodging, and the high-quality complementary offer.

The second factor is called the "alternative leisure and governance" of the destination. Even though these two dimensions may look different, in reality the strategic planning of the destination and the urban law enacted by the governments determine the construction of the alternative leisure offer and the theme parks. On small islands like Gran Canaria, the management of the space is very important in planning the destination's offer and resources. Thus, the variables with the highest scores were obtained for the "sustainability of the alternative leisure offer", with a factorial loading of 0.851 , and the "sustainability of theme parks", which reached a score of 0.808 . Moreover, all of the variables related to the governance of the tourism destination have been assigned to this factor. Therefore, the sustainability of the destination management by the Canary Government, Central Government, and Cabildo Insular obtained scores of $0.676,0.628$, and 0.562 , respectively, whereas 
the sustainability of the strategic planning obtained 0.497 . Both the management and planning of the complementary leisure offers are essential to ensuring the sustainability of this destination because it is a mass and diversified destination in need of promotions and new complementary offers to maintain its competitive level. Given these circumstances, the governance of the tourism destination should lead the strategic planning and the implementation of marketing campaigns.

Table 2. Sustainability factors of the tourism destination of Gran Canaria.

\begin{tabular}{|c|c|c|c|c|c|c|}
\hline & $\begin{array}{l}\text { Key Resources and } \\
\text { Supply Chain }\end{array}$ & $\begin{array}{l}\text { Alternative Leisure } \\
\text { and Governance }\end{array}$ & $\begin{array}{l}\text { Cultural } \\
\text { Offer }\end{array}$ & Security & $\begin{array}{l}\text { Extra-Hotel } \\
\text { Offer }\end{array}$ & Low Cost \\
\hline $\begin{array}{l}\text { Sustainability of the } \\
\text { marine environment }\end{array}$ & 0.851 & & & & & \\
\hline $\begin{array}{l}\text { Sustainability of the foreign } \\
\text { tour operators }\end{array}$ & 0.847 & & & & & \\
\hline Sustainability of the beaches & 0.845 & & & & & \\
\hline Sustainability of airlines & 0.821 & & & & & \\
\hline Sustainability of golf courses & 0.753 & & & & & \\
\hline Sustainability of weather & 0.723 & & & & & \\
\hline $\begin{array}{l}\text { Sustainability of four and } \\
\text { five star hotels }\end{array}$ & 0.696 & & & 0.509 & & \\
\hline Sustainability of theme parks & & 0.808 & & & & \\
\hline $\begin{array}{l}\text { Sustainability of destination } \\
\text { management by the } \\
\text { Canary Government }\end{array}$ & & 0.676 & & & & \\
\hline $\begin{array}{l}\text { Sustainability of destination } \\
\text { management by the } \\
\text { Central Government }\end{array}$ & & 0.628 & & & & \\
\hline $\begin{array}{l}\text { Sustainability of destination } \\
\text { management by the } \\
\text { Gran Canaria Cabildo }\end{array}$ & & 0.562 & 0.523 & & & \\
\hline Sustainability of the health & & & & 0.791 & & \\
\hline Sustainability of the security & & & & 0.783 & & \\
\hline $\begin{array}{l}\text { Sustainability of belonging } \\
\text { to Europe }\end{array}$ & & & & 0.777 & & \\
\hline $\begin{array}{l}\text { Sustainability of extra-hotels } \\
\text { with three or more stars }\end{array}$ & & & & & 0.786 & \\
\hline $\begin{array}{l}\text { Sustainability of Spain's } \\
\text { tour operators }\end{array}$ & 0.511 & & & & 0.608 & \\
\hline $\begin{array}{l}\text { Sustainability of } \\
\text { shopping centers }\end{array}$ & & & & & 0.558 & \\
\hline $\begin{array}{l}\text { Sustainability of extra-hotels } \\
\text { with less than three stars }\end{array}$ & & & & & 0.521 & \\
\hline $\begin{array}{l}\text { Sustainability of } \\
\text { low-cost airlines }\end{array}$ & & & & & & 0.666 \\
\hline Cronbach's Alpha & 0.938 & 0.822 & 0.786 & 0.904 & 0.685 & - \\
\hline
\end{tabular}

KMO 0.757; Chi-Square 1105.15; df 325; Sig. 0.000; Variance explained 76.71\%.

The cultural offer is the next latent dimension and includes the variables of history (0.849), museums (0.841), and culture (0.772). Likewise, another variable is assigned to this factor at the same time, the "sustainability of the destination management of the Cabildo Insular", as the cultural 
policy is designed and implemented by the Cabildo Insular of Gran Canaria. Security is another sustainability factor in tourism destinations. In fact, it could be one of the most important competitive advantages over other tourism destinations. The security of the destination was measured through three basic variables. The first is the "sustainability of health", which obtained a factorial score of 0.791 . The second variable is security, which reached a score of 0.783 . Finally, the legal and political risk were measured by the variable "sustainability of belonging to Europe", which obtained a factorial loading of 0.777 . The variables of "sustainability of four or five-star hotels" (0.509) and "sustainability of hotels with three stars or less" (0.524) have also been allocated to this factor because the experts think the sustainability of high quality service delivery by hotels also depends on the destination's security.

Factor five is called "extra-hotel offer", which includes the different types of apartments, along with the shopping centers and Spanish tour operators. The main characteristic of this destination is that the apartment offer is greater than the hotel offer because the first buildings were built in the 1960s and 1970s, when the main demand was for apartment lodging. Thus, the "extra-hotel offer of three or more stars" obtained a score of 0.786 , and the "extra-hotel offer of less than three stars" reached a loading of 0.521 . This tourism model needs to be complemented by shopping centers to supply products, services, and leisure to customers (0.558). Furthermore, the Spanish tour operators are included because the extra-hotel lodgings need to attract the Spanish market in the summer to compensate for the low demand (0.608). Finally, the low-cost airlines were classified alone in the last factor, without any of the other variables used in the analysis, with a loading of 0.666 . This is a peculiar and interesting result because the low-cost airlines have developed great competitive power in recent years, especially in mass tourism destinations [99]. It is evident that the experts have a specific opinion about their low cost and its effects on the sustainability of the tourism destination. In the next section, we analyze the effects of these factors on the performance and sustainability of the tourism destination analyzed.

\subsection{Performance and Sustainability}

In this section, we present the effects of the six factors on the performance and sustainability of the tourism destination. The performance can be studied from two perspectives. The first is the performance of the tourism destination in terms of the results the destination must achieve to obtain long-term sustainability. This is a supply point of view because it focuses on developing the destination's competitiveness, along with the possibility of also obtaining future performance. Furthermore, sustainability can also be analyzed from the customer perspective. This is the demand point of view, which may or may not be similar to the destination view because the current and future segmentation can influence the conservation or overexploitation of resources. In this context, the strategic planning of the tourism destination must contribute to determining the best market targets to support consistent performance over time. The statistical methodology used to determine the relationship between the sustainability factors and the destination's performance was the regression analysis. Two regression analyses were conducted because there were two perspectives used to measure performance.

\subsection{Tourism Destination Performance}

To determine the tourism destination's performance, the thirteen variables displayed in Table 3 were used. Cronbach's alpha was used to test the structural consistency of this scale, which reached a high score of 0.938 , as well as factorial analysis. To simplify the statistical study, we opted to constrain the output of the factorial analysis to only one factor. The results are presented in Table 3, where it can be observed that the total variance explained was $59.49 \%$, which is a useful result near $60 \%$. The analysis of the factor loadings shows that twelve variables reached a score above 0.7 , and only one, the "sustainability of the cooperation among the economic agents", obtained a loading of 0.49 , near the minimum limit of 0.5 . 
To determine the influence of the sustainability factors on the tourism destination's performance, a regression analysis was carried out, where the dependent variable was the loading of the factor of the destination's performance, and the independent variables were the sustainability factors of the destination (see Table 4 ). The adjusted $R^{2}$ was 0.693 , which is a high result in the social sciences. However, all of the factors obtained a significance level of less than $5 \%$, except the factor of the sustainability of low-cost airlines. These results reveal the direct influence of the first five sustainability factors on the future sustainability of the performance of the tourism destination.

Table 3. Factor analysis of the sustainability of the performance of the tourism destination.

\begin{tabular}{lc}
\hline \multicolumn{1}{c}{ Variables } & Factor Loading \\
\hline Sustainability of tourists' spending & 0.877 \\
Sustainability of the competitiveness of the destination & 0.875 \\
Sustainability of the quality of the destination & 0.843 \\
Sustainability of the stability and increase in employment & 0.810 \\
Sustainability of the profits of the tourism sector & 0.795 \\
Sustainability of the annual occupancy level & 0.790 \\
Sustainability of tourists' satisfaction & 0.782 \\
Sustainability of the impact on the economy of the island & 0.765 \\
Sustainability of the tourism destination & 0.739 \\
Sustainability of the impact on the future development of the island & 0.737 \\
Sustainability of tourists' extra spending & 0.735 \\
Sustainability of the satisfaction of employers in the tourism sector & 0.714 \\
Sustainability of the cooperation among the economics agents & 0.490 \\
Cronbach's Alpha & $\mathbf{0 . 9 3 8}$ \\
\hline
\end{tabular}

KMO 0.885; Chi-Square 572.953; df 78; Sig. 0.000; Variance explained 59.49\%.

Table 4. Regression analysis: sustainability of the performance of the destination.

\begin{tabular}{|c|c|c|c|c|c|}
\hline \multirow{2}{*}{ Independent Variables } & \multicolumn{2}{|c|}{$\begin{array}{l}\text { Unstandardized } \\
\text { Coefficients }\end{array}$} & \multirow{2}{*}{$\begin{array}{l}\begin{array}{l}\text { Standardized } \\
\text { Coefficients }\end{array} \\
\text { Beta }\end{array}$} & \multirow[t]{2}{*}{$t$} & \multirow[t]{2}{*}{ Sig. } \\
\hline & B & Std. Error & & & \\
\hline (Constant) & -0.051 & 0.075 & & -0.676 & 0.503 \\
\hline Factor 1: Key resources and supply chain & 0.705 & 0.076 & 0.718 & 9.332 & 0.000 \\
\hline Factor 2: Alternative leisure and governance & 0.308 & 0.076 & 0.313 & 4.076 & 0.000 \\
\hline Factor 3: Cultural offer & 0.163 & 0.076 & 0.166 & 2.155 & 0.036 \\
\hline Factor 4: Security & 0.244 & 0.076 & 0.248 & 3.229 & 0.002 \\
\hline Factor 5: Extra-hotel offer & 0.158 & 0.076 & 0.161 & 2.092 & 0.042 \\
\hline Factor 6: Low cost & -0.001 & 0.076 & -0.001 & -0.014 & 0.989 \\
\hline
\end{tabular}

Dependent variable: factor of sustainability of the performance of the destination. Adjusted $R^{2} 0.693$.

\subsection{Customer Performance}

Following the same methodology, a factor analysis was carried out with three variables that measure the tourists' performance evaluated by the stakeholders surveyed. Table 5 displays the results of the factor analysis, where only one factor was obtained. All of the factor loadings were above 0.9 , the explained variance was $87.56 \%$, and the Cronbach's alpha was 0.927 . The regression analysis was run using the loadings of the customer performance factor as the dependent variable and the six sustainability factors as independent variables (see Table 6). The adjusted $R^{2}$ was 0.636 , and only two factors are not significant, the "cultural offer" and the "extra-hotel offer". The factors with the highest direct and significant relationship with the sustainability of customers' performance are "key resources and supply chain" $(B=0.562 ;$ sig. $=0.000)$ and "security" $(B=0.532 ;$ sig. $=0.000)$. Furthermore, "alternative leisure and governance" $(B=0.176$; sig. $=0.041)$ and "low cost" $(B=0.184$; sig. $=0.033$ ) also have a significant relationship with customers' performance. 
Table 5. Factor analysis of the performance of customers.

\begin{tabular}{lc}
\hline \multicolumn{1}{c}{ Variables } & Factor Loading \\
\hline Sustainability of the loyalty of customers & 0.942 \\
Sustainability of the emotional experience & 0.939 \\
Sustainability of the image & 0.926 \\
Cronbach's Alpha & $\mathbf{0 . 9 2 7}$ \\
\hline
\end{tabular}

KMO 0.763; Chi-Square 125.811; df 3; Sig. 0.000; Variance explained 87.56\%.

Table 6. Regression analysis: Sustainability of the performance of customers.

\begin{tabular}{|c|c|c|c|c|c|}
\hline \multirow[t]{2}{*}{ Independent Variables } & \multicolumn{2}{|c|}{$\begin{array}{l}\text { Unstandardized } \\
\text { Coefficients }\end{array}$} & \multirow{2}{*}{$\begin{array}{l}\begin{array}{l}\text { Standardized } \\
\text { Coefficients }\end{array} \\
\text { Beta }\end{array}$} & \multirow[t]{2}{*}{$t$} & \multirow[t]{2}{*}{ Sig. } \\
\hline & B & Std. Error & & & \\
\hline (Constant) & -0.031 & 0.083 & & -0.368 & 0.715 \\
\hline Factor 1: Key resources and supply chain & 0.562 & 0.084 & 0.560 & 6.696 & 0.000 \\
\hline Factor 2: Alternative leisure and governance & 0.176 & 0.084 & 0.176 & 2.100 & 0.041 \\
\hline Factor 3: Cultural offer & 0.117 & 0.084 & 0.117 & 1.392 & 0.171 \\
\hline Factor 4: Security & 0.532 & 0.084 & 0.530 & 6.337 & 0.000 \\
\hline Factor 5: Extra-hotel offer & 0.066 & 0.084 & 0.065 & 0.782 & 0.438 \\
\hline Factor 6: Low cost & 0.184 & 0.084 & 0.184 & 2.195 & 0.033 \\
\hline
\end{tabular}

Dependent variable: factor of sustainability of the performance of the customers. Adjusted $R^{2} 0.636$.

\subsection{Discussion of the Results}

The study contributes to determining the key factors in the sustainability of a tourism destination, explaining $76.71 \%$ of the variance, similar to the drivers of tourism performance proposed by Assaf and Josiassen [68]. Although the specific characteristics of each destination can orient the type of variables to use depending on the main resources and target market, this study gives a broad view of the variables to take into account in establishing the main elements that support the sustainability of a tourism destination. This vision is the consequence of selecting a tourism destination such as Gran Canaria, where it is possible to find different types of tourism offers. The most important market is the sun and beach segment, but, due to the peculiarities of the island studied, there are other alternative offers, such as rural, museum, cultural, sports, leisure, maritime, mountain, biology, and so on. Moreover, the lodging offer is not specialized because Gran Canaria has a variety of lodgings in hotel and extra-hotel complexes, providing a wide range of target market possibilities. All of these characteristics can be observed in the six sustainability factors extracted, which highlight low-cost airlines, which have been assigned to one unique factor. This may indicate that low-cost airlines promote mass tourism, according to Ivars et al. [99], which, in some cases, can be contrary to the sustainability of the tourism destination. In this study, the experts considered that low-cost airlines had to be analyzed as a specific and differentiated variable because they have a unique effect on the sustainability of the destination.

The destination's most important resources, according to Likewise, Byrd et al. [43], are included in the same factor with the main competitive elements of the tourism supply chain. This factor shows the key target market of the destination because the weather and the beaches are the main competitive advantages. As the supply chain elements are essential to sustaining a destination, in this first factor the variables related to the hotel offer, tour operators, and airlines were also included, according to the Tourism Supply Chain proposed by Rodríguez-Díaz and Espino-Rodríguez [11]. The security is another basic factor in a destination's competitiveness, and Gran Canaria has a high level in terms of health, physical, and legal security because it belongs to the European Union. This factor aligns with what was proposed by different authors such as Cartwright [82], Page and Meyer [83], Baker et al. [85], and Tarlow [89]. 
On the other hand, the performance of the tourism destination was also studied in order to determine key and weak sustainability factors. This is a novel way to analyze the performance of tourism destinations because the studies developed in this line of research, such as those by Barros et al. [91] and Aissa and Goaied [55], do not consider the sustainability of the performance in destinations. Likewise, performance was analyzed in two ways: the destination and customer performances. The variables used to measure the performance of the destination were integrated in one factor that explains $59.49 \%$ of the variance. Moreover, the performance of the customer was measured through a factor that explains $87.56 \%$ of the variance.

The regression analysis demonstrated that these two factors, along with "alternative leisure and governance", have significant and direct relationships with both destination and customer performance. The main conclusion about the sustainability factor is that the experts consider these three factors to be the keys to sustaining long-term performance. Thus, the governance and strategic planning of the destination must be oriented toward reinforcing high quality resources and offers in order to maintain the destination's competitiveness and sustainability. This is a main implication of the present study because it provides essential information for the governance and strategic planning of the tourism destination, based on the research orientation proposed by authors such as Sauter and Leisen [37], Sheehan and Ritchie [12], Fornica and Kothari [36], Bramwell and Lane [90], and Pike and Page [13].

Other attributes of the destination do not have the same influence on performance. In this context, the cultural offer is directly related to the destination's performance, but the result is not significant for the customers' performance. One explanation for these results could be the experts' view of culture and history, which are very interesting but not sufficiently familiar to visitors. From this perspective, culture can be a potential resource to develop in the future, but currently the majority of the customers look for other characteristics of the destination. A similar situation exists with the extra-hotel offering, which has a direct and significant relationship with the destination's performance, but not with the customers' performance. As we pointed out above, there is a large offer of apartments, and they are very important in this destination, but the buildings are quite old and need renovation. From the point of view of experts, the extra-hotel offer is very important to sustain the level of occupancy, employment, and economic development of the island. However, at the same time, the experts consider that this offer has no influence on the sustainability of the customers' performance, which might be related to the outdated extra-hotel offer. Therefore, we can conclude that the renovation of the extra-hotel offer would provide a strategic advantage for the future sustainability of the destination. Furthermore, it is necessary for the renovation of this type of lodging to be linked to the image and emotional experience of the tourists, in order to maintain their level of loyalty to the destination. It is important to highlight the weaknesses in order to guide the governance and planning of the destination $[12,13,37]$.

The low-cost airlines require a specific analysis because the results show a significant and direct relationship with customers' performance, but we find no evidence for the relationship with the destination's performance. It is obvious that in recent years the low-cost airlines have improved their market share by offering very cheap tickets, but this increase in the demand can have negative effects on the sustainability of a destination. On the one hand, an excessive mass tourism can produce irreversible damages to the environment; on the other hand, if mass tourism reduces the price and the margin, this can cause low profitability or losses in tourism companies. Thus, low cost is a great opportunity for customers because it reduces the cost of the flight, as Ivars et al. [99] noted. However, if the destination cannot channel the increase in demand and income into profitability and the sustainability of the destination's environment and economy, long-term performance will not be guaranteed. Some destinations can reconcile different market segments without losing competitiveness, but this is not always the case because a great imbalance in favor of the low cost demand could have the opposite effect on the destination's sustainability in the long term.

Finally, the results obtained in this study show that the effective management of a tourism destination requires the application of a specific methodology based on the sustainability and performance of the resources and capabilities. In particular, it is necessary to determine the key 
and weak sustainability factors and their relationship with long-term performance. This is a new way to understand governance and strategic planning from a theoretical and practical perspective, which is the basis of the tourism destination's sustainable management. This discipline must be developed from a practical point of view, in order to guide stakeholders' decisions in tourism destinations.

\section{Conclusions}

Sustainability and performance are key aspects in managing and maintaining the competitiveness of tourism destinations. This study identified the sustainability factors of a tourism destination characterized by the differentiation of the offer and high demand. The data were collected through surveys administered to stakeholders and experts because this method is widely used in research about tourism destinations and provides successful results. The factors obtained were related to the performance of the destination and customers by means of regression analysis. The results demonstrated that in the tourism destination studied, there are six sustainability factors that are quite similar to the destination drivers proposed by Assaf and Josiassen [68]. However, in this study, all of the variables used were evaluated in relation to sustainability, and the variables were assigned to factors according to the importance of the resources and capabilities of the specific destination analyzed. The first factors deal with the "key resources and supply chain", including the variables related to the most important resources and elements of the tourism supply chain that contribute to the destination's competitiveness. The second factor contained the variables of "alternative leisure and governance" because Gran Canaria is a small island where the management and planning of the space is essential to correctly allocating the resources. In this context, the leisure activities need large areas that must be defined properly in order to obtain the sustainable development of the destination. The cultural offer is another pillar of sustainability, based on the history, museums, and culture, with the peculiarity that the island's government has a great influence on cultural policy. Likewise, security is another basic factor in the destination's sustainability because Gran Canaria belongs to Europe, it has good health infrastructures, and the security is very high. This may be one of the most important competitive advantages over other destinations. Another specific characteristic of the destination analyzed is the "extra-hotel offer" factor, which includes most of the tourist beds because this destination began in the 1960s and 1970s when the main demand was for apartments. Finally, the experts considered that low-cost airlines constitute a specific factor because they have a direct effect on the destination's sustainability and performance.

The regression analysis demonstrated that the experts think there are three key sustainability factors related to the long-term performance of the destination and customers: "key resources and supply chain", "alternative leisure and governance", and "security". Nevertheless, the factors "cultural offer" and "extra-hotel offer" also have a positive impact on the sustainability of the destination's performance, but they are not significant in the customers' performance. According to the experts, the only factor that does not have a direct relationship with the destination's long-term performance is that of "low cost" airlines. By contrast, low cost obtains a significant and direct relationship with customers' performance. We can conclude that low cost can be a great opportunity for customers, but if the increase in demand and incomes are not managed in terms of the destination's environmental and economic sustainability, the future performance will not be guaranteed.

In light of the results obtained, on the one hand, the destination's governance and strategic planning must be oriented toward reinforcing high-quality resources and offers in order to maintain the destination's competitiveness and sustainability, promote culture and history, and foster the renovation of the extra-hotel offer. On the other hand, the low cost offer can be planned adequately to maintain a sustainable level of performance without producing negative effects on the natural, social, and economic environment. This study demonstrates that the sustainable factors and their relationships with performance are critical aspects in managing tourism destinations. However, this study has been tested in a mass tourism destination and, although it offers a variety of activities, there are other types of destinations with different characteristics and strategic orientations. Finally, the results obtained 
confirm that the tourism destination's sustainable management can be applied using a framework based on the key and weak sustainability factors and the long-term performance of the destination and customers. Future research should use other variables, with the aim of adapting and testing the proposed methodology in other specific destinations. At the same time, the variables used to measure the types of performance could be studied, in order to validate them in other destinations and analyze whether other variables can be used in the statistical analysis. Regarding the study limitations, it is necessary to highlight that the results obtained are not generalizable because only one destination was analyzed in an exploratory way, and the sample used was not very large. Therefore, future studies should consider broader groups of stakeholders in various tourist destinations and include qualitative analysis. Another limitation of this study is that the evaluations of the sustainable factors and the performance have only been determined from the perspective of the stakeholders, and the opinions of the customers have not been analyzed. Future studies should determine the main sustainability factors and the performance based on customer evaluations, and compare the results with those obtained from the perspective of the stakeholders.

Acknowledgments: We appreciate the helpful comments and suggestions of academic editor Rachel Dodds and three anonymous reviewers.

Author Contributions: The authors have contributed equally in the research design and development, the data analysis, and the writing of the paper. The authors have read and approved the final manuscript.

Conflicts of Interest: The authors declare no conflicts of interest.

\section{References}

1. McKercher, B. A chaos approach to tourism. Tour. Manag. 1999, 20, 425-434. [CrossRef]

2. Gunn, C. Tourism Planning, 3rd ed.; Taylor and Francis: London, UK, 1994.

3. Pearce, D. Tourism Development; Longman: New York, NY, USA, 1989.

4. Haugland, S.A.; Ness, H.; Gronseth, B.O.; Aarstad, J. Development of tourism destinations: An integrated multilevel perspective. Ann. Tour. Res. 2011, 38, 268-290. [CrossRef]

5. Hu, Y.Z.; Ritchie, J.R.B. Measuring destination attractiveness: A contextual approach. J. Travel Res. 1993, 32, 25-34.

6. Buhalis, D. Marketing the competitive destination of the future. Tour. Manag. 2000, 21, 97-116. [CrossRef]

7. Murphy, P.; Pritchard, M.; Smith, B. The destination product and its impact on traveler perceptions. Tour. Manag. 2000, 21, 43-52. [CrossRef]

8. Farrell, B.H.; Twining-Ward, L. Reconceptualizing tourism. Ann. Tour. Res. 2004, 31, 274-295. [CrossRef]

9. Hassan, S.S. Determinants of market competitiveness in an environmentally sustainable tourism industry. J. Travel Res. 2000, 38, 239-245. [CrossRef]

10. Beritelli, P.; Bieger, T.; Laesser, C. Destination governance. Using corporate governance theories as a foundation for effective destination management. J. Travel Res. 2007, 46, 96-107.

11. Rodríguez-Díaz, M.; Espino-Rodríguez, T.F. A model of strategic evaluation of a tourism destination based on internal and relational capabilities. J. Travel Res. 2008, 46, 368-380. [CrossRef]

12. Sheehan, L.R.; Ritchie, J.R.B. Destination stakeholders: Exploring identity and salience. Ann. Tour. Res. 2005, 32, 711-734. [CrossRef]

13. Pike, S.; Page, S.J. Destination Marketing Organizations and destination marketing: A narrative analysis of the literature. Tour. Manag. 2014, 41, 202-227. [CrossRef]

14. Choi, H.C.; Sirakaya, E. Sustainability indicators for managing community tourism. Tour. Manag. 2006, 27, 1274-1289. [CrossRef]

15. Hall, C.M.; Lew, A.A. The geography of sustainable tourism development: Introduction. In Sustainable Tourism: Geographical Perspectives; Hall, C.M., Lew, A.A., Eds.; Addison Wesley Longman Ltd.: New York, NY, USA, 1998; pp. 1-24.

16. Hidinger, L.A. Measuring the impact of ecotourism on animal populations: A case study of Tikal National Park, Guatemala. Yale For. Environ. Bull. 1996, 99, 49-59.

17. Liu, Z. Sustainable tourism development: A critique. J. Sustain. Tour. 2010, 11, 459-475. [CrossRef] 
18. Mowforth, A.; Munt, I. Tourism and Sustainability: New Tourism in the Third World; Routledge: London, UK, 1998.

19. Singh, S.C. Impact of Tourism on Mountain Environment; Research India Publications: Delhi, India, 1989.

20. Akis, S.; Peristianis, N.; Warner, J. Residents' attitudes to tourism development: The case of Cyprus. Tour. Manag. 1996, 17, 481-494. [CrossRef]

21. Butler, R.W.; Boyd, S. Tourism E National Parks; John Wiley: Chichester, UK, 2000.

22. Cater, E.A. Ecotourism in the third world: Problems for sustainable tourism development. Tour. Manag. 1993, 14, 85-89. [CrossRef]

23. Hall, C.M.; McArthur, S. Integrated Heritage Management: Principles \& Practice; The Stationery Office: London, UK, 1998.

24. Haralambopoulos, N.; Pizam, A. Perceived impacts of tourism: The case of Samos. Ann. Tour. Res. 1996, 23, 503-526. [CrossRef]

25. Healy, R.G. Tourism merchandise' as a means of generating local benefits from ecotourism. J. Sustain. Tour. 1994, 2, 137-151. [CrossRef]

26. Place, S.E. Ecotourism for sustainable development: Oxymoron or plausible strategy? GeoJournal 1995, 35, 161-174. [CrossRef]

27. Richard, G.; Hall, D. Tourism \& Sustainable Community Development; Routledge: New York, NY, USA, 2000.

28. Pavlovich, K. The evolution and transformation of a tourism destination network: The Waitomo Caves, New Zealand. Tour. Manag. 2003, 24, 203-216. [CrossRef]

29. Cai, L.A.; Qui, H.; Li, G. Towards a competitive destination brand in a mass market. Tour. Anal. 2007, 12, 463-472. [CrossRef]

30. Pike, S. Destination brand positioning slogans: Towards the development of a set of accountability criteria. Acta Turística 2004, 16, 102-124.

31. Mazanec, J.; Wober, K.; Zins, A.H. Tourism destination competitiveness: From definition to explanation. J. Travel Res. 2007, 46, 86-95. [CrossRef]

32. Leiper, N. Why 'the tourism industry' is misleading as a generic expression: The case for the plural variation, 'tourism industries'. Tour. Manag. 2008, 29, 237-251. [CrossRef]

33. Go, F.; Govers, R. Integrated quality management for tourist destinations: A European perspective on achieving competitiveness. Tour. Manag. 2000, 21, 116-126. [CrossRef]

34. Dwyer, L.; Kim, C. Destination competitiveness: Determinants and indicators. Curr. Issues Tour. 2003, 6, 369-414. [CrossRef]

35. Gomezelj, D.O.; Mihalic, T. Destination competitiveness: Applying different models, the case of Slovenia. Tour. Manag. 2008, 29, 294-307. [CrossRef]

36. Fornica, S.; Kothari, T.H. Strategic destination planning: Analyzing the future of tourism. J. Travel Res. 2008, 46, 355-367. [CrossRef]

37. Sauter, E.T.; Leisen, B. Managing stakeholders: A tourism planning model. Ann. Tour. Res. 1999, 26, 312-328. [CrossRef]

38. Ritchie, J.R.B.; Crouch, G. The Competitive Destination: A Sustainable Tourism Perspective; CABI Publishing: Oxon, UK, 2003.

39. Enright, M.J.; Newton, J. Tourism destination competitiveness: A quantitative approach. Tour. Manag. 2004, 25, 777-788. [CrossRef]

40. The United Nations World Tourism Organization (UNWTO). Policy and Practice for Global Tourism; UNWTO: Madrid, Spain, 2011.

41. Gretzel, U.; Fesenmaier, D.R.; Fornica, S.; O'Leary, J.T. Searching for the future: Challenges faced by destination marketing organizations. J. Travel Res. 2006, 45, 116-126. [CrossRef]

42. Aas, C.; Ladkin, A.; Fletcher, J. Stakeholder collaboration and heritage management. Ann. Tour. Res. 2005, 32, $28-48$.

43. Byrd, E.T.; Cárdenes, D.A.; Greenwood, J.B. Factors of stakeholder understanding of tourism: The case of Eastern North Carolina. Tour. Hosp. Res. 2008, 8, 192-204. [CrossRef]

44. Bornhorst, T.; Ritchie, J.R.B.; Sheehan, L. Determinants of tourism success for DMOs \& destinations: An empirical examination of stakeholders' perspectives. Tour. Manag. 2010, 31, 572-589.

45. International Union for the Conservation of Nature and Natural Resources (IUCN). World Conservation Strategy; IUCN: Gland, Switzerland, 1980. 
46. World Commission on Environment and Development (WCED). Our Common Future; Oxford University Press: Oxford, UK, 1987; p. 43.

47. Butler, R.W. Sustainable tourism: A state of the art review. Tour. Geogr. 1999, 1, 7-25. [CrossRef]

48. Page, S.J.; Dowling, R.K. Ecotourism; Prentice-Hall: Harlow, UK, 2002.

49. World Trade Organization (WTO). The Concept of Sustainable Tourism. Available online: http://www. world-tourism.org/sustainable/concepts.htm (accessed on 15 December 2001).

50. Saarinen, J. Traditions of sustainability in tourism studies. Ann. Tour. Res. 2006, 33, 1121-1140. [CrossRef]

51. Ko, T.G. Development of a tourism sustainability assessment procedure: A conceptual approach. Tour. Manag. 2005, 26, 431-445. [CrossRef]

52. Mihalic, T. Environmental management of a tourist destination: A factor of tourism competitiveness. Tour. Manag. 2000, 21, 65-78. [CrossRef]

53. Soteriou, E.C.; Coccossis, H. Integrating sustainability into the strategic planning of national tourism organizations. J. Travel Res. 2009, 49, 191-205. [CrossRef]

54. Middleton, V.T.C.; Hawkins, R. Sustainable Tourism: A Marketing Perspective; Butterworth-Heinemann: Oxford, UK, 1998.

55. Aissa, S.B.; Goaied, M. Performance of tourism destinations: Evidence from Tunisia. J. Hosp. Tour. Res. 2014. [CrossRef]

56. Chon, K.S. Tourism destination image modification process: Marketing implications. Tour. Manag. 1991, 12, 68-72. [CrossRef]

57. Baloglu, S.; Mangaloglu, M. Tourism destination images of Turkey, Egypt, Greece, and Italy as perceived by US-based tour operators and travel agents. Tour. Manag. 2001, 22, 1-9. [CrossRef]

58. Govers, R.; Go, F.M.; Kumar, K. Promoting tourism destination image. J. Travel Res. 2007, 46, 15-23. [CrossRef]

59. Wöber, K.W.; Fesenmaier, D.R. A multi-criteria approach to destination benchmarking: A case study of state tourism advertising programs in the United States. J. Travel Tour. Mark. 2004, 16, 1-18. [CrossRef]

60. Papatheodorou, A. Exploring competitiveness in Mediterranean resorts. Tour. Econ. 2002, 8, $133-150$. [CrossRef]

61. Oppermann, M. Tourism destination loyalty. J. Travel Res. 2000, 39, 78-84. [CrossRef]

62. Alegre, J.; Juaneda, C. Destination loyalty: Consumers' economic behavior. Ann. Tour. Res. 2006, 33, 684-706. [CrossRef]

63. Fuchs, M. Strategy development in tourism destination: A DEA approach. Pozn. Univ. Econ. Rev. 2004, 4, 52-73.

64. Cracolici, M.F.; Nijkamp, P.; Rietveld, P. Assessment of Tourist Competitiveness by Analyzing Destination Efficiency; VU University Amsterdam: Amsterdam, The Netherlands, 2006.

65. Bosetti, V.; Cassinelli, M.; Lanza, A. Benchmarking in Tourism Destination, Keeping in Mind the Sustainable Paradigm; Physica-Verlag: Heidelberg, Germany, 2006.

66. Peypoch, N.; Solonandrasana, B. On E-attraction tourism destination: Extension and application. In Advances in Modern Tourism Research; Matias, A., Neto, P., Nijkamp, P., Eds.; Springer-Verlag: New York, NY, USA, 2007; pp. 293-306.

67. Botti, L.; Peypoch, N.; Robinot, E.; Solonadrasana, B. Tourism destination competitiveness: The French case. Eur. J. Tour. Res. 2009, 2, 5-24.

68. Assaf, A.G.; Josiassen, A. Identifying and ranking the determinants of tourism performance: A global investigation. J. Travel Res. 2012, 51, 388-399. [CrossRef]

69. ISTAC. Canarian Government Estadísticas Sector Servicios. Available online: http://www. gobiernodecanarias.org/istac/ (accessed on 20 June 2013).

70. Aguiló, E.; Alegre, J.; Sard, M. The persistence of the sun and sand tourism model. Tour. Manag. 2005, 26, 219-231. [CrossRef]

71. Zhang, X.; Song, H.; Huang, G.Q. Tourism supply chain management: A new research agenda. Tour. Manag. 2009, 30, 345-358. [CrossRef]

72. Green, B.C.; Chalip, L. Sport tourism as the celebration of subculture. Ann. Tour. Res. 1998, 25, $275-291$. [CrossRef]

73. Hinch, T.D.; Higham, J.E.S. Sport tourism: A framework for research. Int. J. Tour. Res. 2001, 3, 45-58. [CrossRef] 
74. Gibson, H.J.; Willming, C.; Holdnak, A. Small-scale event sport tourism: Fans as tourists. Tour. Manag. 2003, 24, 181-190. [CrossRef]

75. Jansen-Verbeke, M.; Dietvorst, A. Leisure, recreation, tourism: A geographic view on integration. Ann. Tour. Res. 1987, 14, 361-375. [CrossRef]

76. Getz, D. Tourist shopping villages: Development and planning strategies. Tour. Manag. 1993, 14, $15-26$. [CrossRef]

77. Bigné, J.E.; Andreu, L.; Gnoth, J. The theme park experience: An analysis of pleasure, arousal and satisfaction. Tour. Manag. 2005, 26, 833-844. [CrossRef]

78. Lin, C.H.; Morais, D.B.; Hou, J.S. Examining the role of cognitive and affective image in predicting choice across natural, developed, and theme-park destinations. J. Travel Res. 2007, 46, 183-194. [CrossRef]

79. Silberberg, T. Cultural tourism and business opportunities for museums and heritage sites. Tour. Manag. 1995, 16, 361-365. [CrossRef]

80. Medina, L.K. Commoditizing culture: Tourism and Maya identity. Tour. Manag. 2003, 30, 353-368. [CrossRef]

81. Lozano-Oyola, M.; Blancas, F.J.; González, M.; Caballero, R. Sustainable tourism indicators as planning tools in cultural destinations. Ecol. Indic. 2012, 18, 659-675. [CrossRef]

82. Cartwright, R. Reducing the health risks associated with travel. Tour. Manag. 2000, 6, 159-167. [CrossRef]

83. Page, S.J.; Meyer, D. Tourist accident: An exploratory analysis. Ann. Tour. Res. 1996, 23, 666-690. [CrossRef]

84. Wilks, J.; Page, S.J. Current status of tourist health and safety. In Managing Tourist Health and Safety in the New Millennium; Wilks, J., Page, S.J., Eds.; Pergamon: Oxford, UK, 2003; pp. 3-15.

85. Baker, M.; Page, S.J.; Meyer, D. Urban visitor perceptions of safety during a special event. J. Travel Res. 1996, 41, 355-361. [CrossRef]

86. Dimanche, F.; Lepetic, A. New Orleans tourism crime: A case study. J. Travel Res. 1999, 38, 19-23. [CrossRef]

87. Mawby, R.I. Tourist's perception of security: The risk fear paradox. Tour. Econ. 2000, 6, 109-121. [CrossRef]

88. Pizam, A. A comprehensive approach to classifying acts of crime and violence at tourism destinations. J. Travel Res. 1999, 38, 5-12. [CrossRef]

89. Tarlow, P.E. Crime and tourism. In Tourism in Turbulent Times; Wilks, J., Pendergast, D., Leggat, P., Eds.; Elsevier: Oxford, UK, 2006; pp. 93-105.

90. Bramwell, B.; Lane, B. Critical research on the governance of tourism and sustainability. J. Sustain. Tour. 2011, 19, 411-421. [CrossRef]

91. Barros, C.P.; Botti, L.; Peypoch, N.; Robinot, E. Performance of French destinations: Tourism attraction perspectives. Tour. Manag. 2011, 32, 141-146. [CrossRef]

92. Claver-Cortés, E.; Molina-Azorín, J.F.; Pereira-Moliner, J. Competitiveness in mass tourism. Ann. Tour. Res. 2007, 34, 727-745. [CrossRef]

93. Keane, M.J. Quality and pricing in tourism destinations. Ann. Tour. Res. 1997, 24, 117-130. [CrossRef]

94. Kozak, M.; Rimmington, M. Tourist satisfaction with Mallorca, Spain, as an off-season holiday destination. J. Travel Res. 2000, 33, 260-269. [CrossRef]

95. Chi, C.G.Q.; Qu, H. Examining the structural relationships of destination image, tourist satisfaction and destination loyalty: An integrated approach. Tour. Manag. 2008, 29, 624-636. [CrossRef]

96. Jamal, T.B.; Getz, D. Collaboration theory and community tourism planning. Ann. Tour. Res. 1995, 22, 186-204. [CrossRef]

97. Blain, C.; Stuart, E.L.; Ritchie, J.R.B. Destination branding: Insights and practices from destination management organizations. J. Travel Res. 2005, 43, 328-338. [CrossRef]

98. Wang, N. Rethinking authenticity in tourism experience. Ann. Tour. Res. 1999, 26, 349-370. [CrossRef]

99. Ivars i Baibal, J.A.; Rodríguez Sánchez, I.; Vera Rebollo, J.F. The evolution of mass tourism destinations: New approaches beyond deterministic models in Benidorm (Spain). Tour. Manag. 2013, 34, 184-195. [CrossRef]

(C) 2016 by the authors; licensee MDPI, Basel, Switzerland. This article is an open access article distributed under the terms and conditions of the Creative Commons Attribution (CC-BY) license (http://creativecommons.org/licenses/by/4.0/). 